\title{
Synthesis and Evaluation of Some Uracil Nucleosides as Promising Anti-Herpes Simplex Virus 1 Agents
}

\author{
Samir Mohamed Awad ${ }^{1}$, Shima Mahmoud Ali ${ }^{2}$, Yara Essam Mansour ${ }^{1}$ and Samar Said Fatahala ${ }^{1, *}$ \\ 1 Department of Pharmaceutical Organic Chemistry, Faculty of Pharmacy, Helwan University, Ain-Helwan, \\ Cairo 11795, Egypt; Samir.Awad@pharm.helwan.edu.eg (S.M.A.); \\ Yara_mansour@pharm.helwan.edu.eg (Y.E.M.) \\ 2 Department of Microbiology and Immunology, Faculty of Pharmacy, Helwan University, Ain-Helwan, \\ Cairo 11795, Egypt; shaima.mn@gmail.com \\ * Correspondence: samar_saleh@pharm.helwan.edu.eg; Tel.: +20-2-2554-1601; Fax: +20-2-2554-1601
}

\begin{abstract}
Since herpes simplex virus type 1 (HSV-1) infection is so widespread, several antiviral drugs have been developed to treat it, among which are uracil nucleosides. However, there are major problems with the current medications such as severe side-effects and drug resistance. Here we present some newly synthesized cyclic and acyclic uracil nucleosides that showed very promising activity against HSV-1 compared to acyclovir.
\end{abstract}

Keywords: uracil; cyclic nucleosides; acyclic nucleosides; antiviral activities

Citation: Awad, S.M.; Ali, S.M.;

Mansour, Y.E.; Fatahala, S.S.

Synthesis and Evaluation of Some Uracil Nucleosides as Promising Anti-Herpes Simplex Virus 1 Agents. Molecules 2021, 26, 2988. https:// doi.org/10.3390/molecules26102988

Academic Editor: Patricia

Dias Fernandes

Received: 27 April 2021

Accepted: 16 May 2021

Published: 18 May 2021

Publisher's Note: MDPI stays neutral with regard to jurisdictional claims in published maps and institutional affiliations.

Copyright: (c) 2021 by the authors. Licensee MDPI, Basel, Switzerland. This article is an open access article distributed under the terms and conditions of the Creative Commons Attribution (CC BY) license (https:// creativecommons.org/licenses/by/ $4.0 /)$.

\section{Introduction}

Viruses are the main causes of fatal infectious diseases affecting humans worldwide [1]. One of the major viral human pathogens is the Herpes virus family, which has the potential to cause lifelong latent infection. Life-threatening diseases can result from the primary infections of the herpes viruses and also from their reactivation, especially in immunecompromised patients [2]. Herpesviridae is a large family of DNA viruses consisting of eight members that are grouped according to biological and genomic similarities into three subfamilies $(\alpha, \beta$, and $\gamma)$ [3]. The $\gamma$ subfamily includes Kaposi's sarcoma associated with herpes and the Epstein-Barr virus (EBV). The $\beta$ subfamily includes cytomegalovirus and the human herpesviruses HHV-6 and HHV-7 [4,5]. The $\alpha$ subfamily includes herpes simplex viruses (HSV-1, HSV-2) and the varicella zoster virus (VZV) [3,6,7], which are among the most common human diseases. HSV usually becomes dormant until reactivated under certain conditions, like emotional stress, fever, and immunosuppression [1]. Symptoms of HSV vary from mild vesicular lesions [8], oral and perioral infections, cold sores and keratitis to serious symptoms such as corneal blindness, encephalitis and disseminated neonatal infections [1,2].

The U.S. Food and Drug Administration (FDA) approved antiherpetic drugs belonging to three classes. The first class consists of nucleoside (purine and pyrimidine) analogues in which the sugar moiety is changed $[2,8,9]$. This class includes acyclovir (ACV) [10] (9-(2-hydroxyethoxymethyl) guanine) [1,2], its valyl ester prodrug valacyclovir (VCV), famciclovir (FCV) (the oral prodrug of penciclovir (PCV)) [11], and ganciclovir (GCV). The second class pertains to acyclic nucleoside phosphonate (ANP) derivatives, and the drug here is cidofovir (CDV). The third class contains pyrophosphate analogues to which belongs phosphonoformic acid or foscarnet (FOS) [7]. Generally speaking, ACV and related drugs are highly successful in treating HSVs [12] because they possess the advantages of metabolic stability, low toxicity and high antiviral potency [2]. However, because of prolonged use, resistant viral strains have emerged, leading to serious clinical problems like severe mucosal infection and visceral dissemination, especially in immunocompromised patients [12]. After their discovery, ANPs, including CDV, became a fundamental class of 
antiviral drugs for their durable antiviral effects, including on viruses that had become resistant to other drugs [13]. Recently, both CDV and FOS were used to treat severe HSV infections that had become resistant to ACV or FCV [8] but with poor results. The use of CDV and GCV is limited due to poor oral bioavailability and the nephrotoxicity of CDV and hematological toxicity of GCV [2]. Current approaches for improving anti-herpetic activity include a series of 5-substituted 2'-deoxyuridine derivatives such as 5-halovinyluracil nucleosides (e.g., brivudin (BVDU, Zostex ${ }^{\circledR}$, Zerpex $^{\circledR}$ ), and the arabinosyl analogues BVaraU and Sorivudin, which showed particularly potent anti-VZV activity. However, due to the potential toxicity of (BVU), its use as a therapeutic agent is limited [8]. For the abovementioned reasons, research into 5-substituents other than the 5-halovinyl group was encouraged, and for this the newly prepared cyclic sugar moieties have demonstrated specific anti-VZV activity [14-18]. The chemical structures of some of the drugs mentioned above, together with other potent anti-viral agents belonging to the class of cyclic and acyclic nucleoside analogues, are discussed in Figure 1.

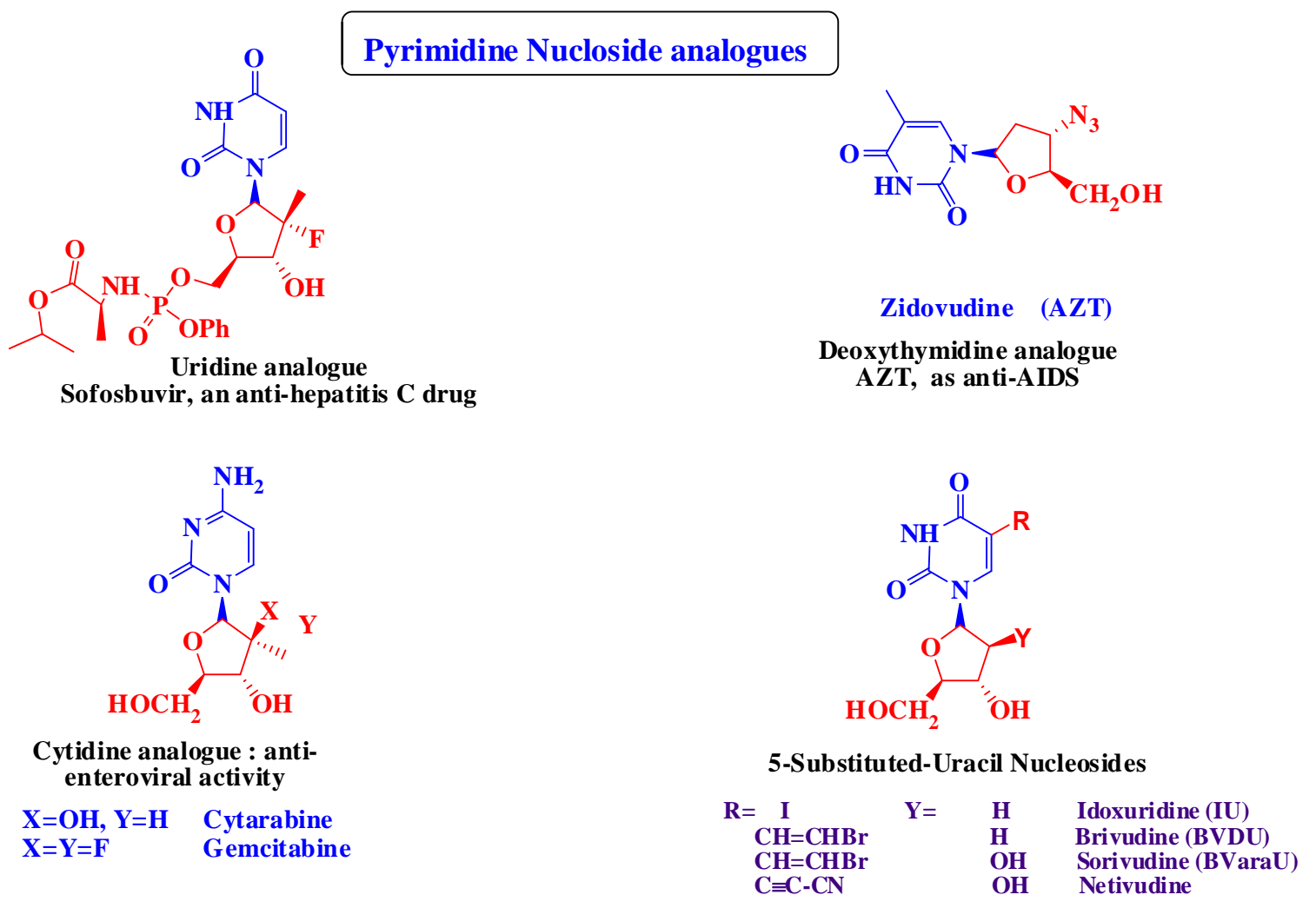

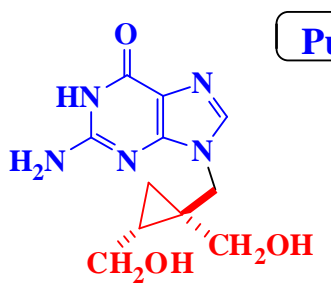

A5021 (Guanosine acyclic nucleosides; ef fective against herpetic activity

\section{Purine Nucleoside analogues}<smiles>[R]Cn1cnc2c(=O)[nH]c(N)nc21</smiles>

Guanosine acyclic nucleosides act as anti-metabolite

$$
\begin{array}{ll}
\mathrm{R}=\mathrm{OCH}_{2} \mathrm{CH}_{2} \mathrm{OH} & \text { Acyclovir (Potent anti-virus) } \\
\mathrm{R}=\mathrm{CH}_{2} \mathrm{CH}\left(\mathrm{CH}_{2} \mathrm{OH}\right) \mathrm{CH}_{2} \mathrm{OH} & \text { Penciclovir (anti-herpes) } \\
\mathrm{R}=\mathrm{OCH}_{(}\left(\mathrm{CH}_{2} \mathrm{OH}\right) \mathrm{CH}_{2} \mathrm{OH} & \text { Ganciclovir (f or treating of } \\
\text { human cytomegalovirus) } &
\end{array}
$$

Figure 1. Some potent cyclic and acyclic nucleoside analogues used as potent anti-viral agents [19-23]. 
The COVID-19 pandemic has driven the whole world into a rush to invent anti-COVID drugs [24,25]. The RNA-dependent RNA polymerase (RdRp) is essential for coronaviral replication and transcription, and that marks it as the primary target for the antiviral nucleotide analogue drugs [26,27]. Researchers have identified quite a few molecules that interfere with the polymerase reaction, some of which are already FDA-approved to treat other viruses [28,29]. Among these drugs is favipiravir, which has been proven effective in clinical trials to treat SARS-CoV-2 [29-31] and has the ability to shut down the polymerase reaction. Our immune system can easily destroy SARS-CoV-2 if it can stop the polymerase reaction [30,32]. The target of all currently available drugs for treating herpes infections is a viral DNA polymerase [33]. Chemically, polymerase inhibitors are classified into two main groups [34,35]: nucleoside analogues and non-nucleoside inhibitors (pyrophosphate derivatives) [36,37]. Among these drugs, cidofovir is an acyclic nucleoside phosphonate approved to treat AIDS and used to treat many other DNA viral infections (e.g., HSV and the papillomavirus) [38,39]. Some of the approved anti-viral drugs are being used in clinical trials to treat SARS-CoV-2, and they are discussed in Figure 2.

\section{Guanosine acyclic nucleosides (Anti-herpes)}<smiles>CC(=O)OC(CCn1cnc2c(=O)[nH]c(N)nc21)OC(C)=O</smiles>

Famciclovir (FCV)
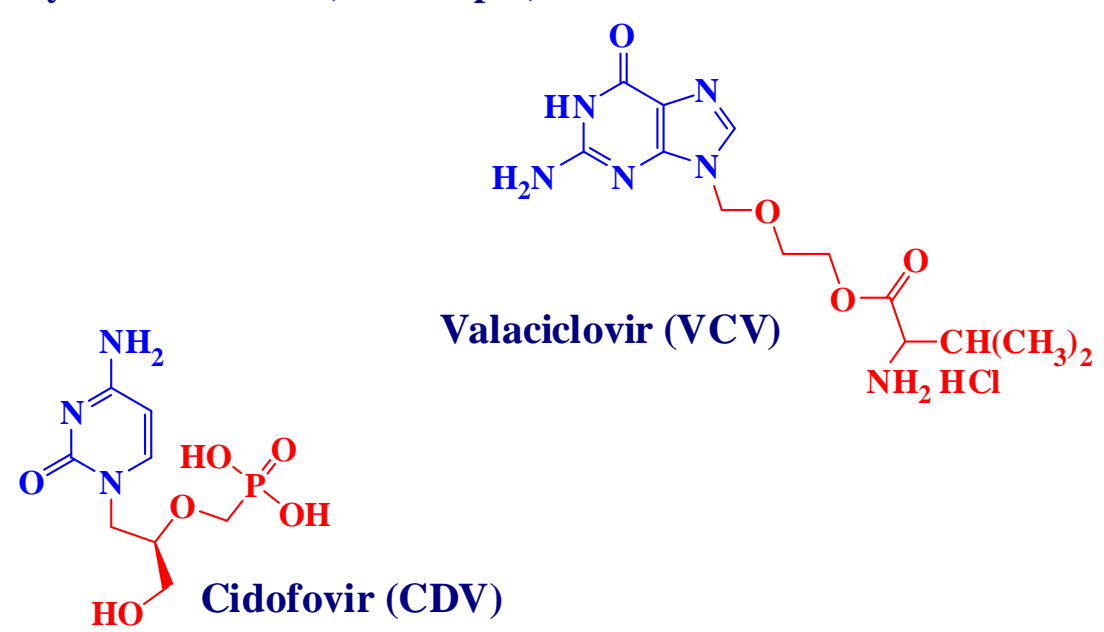

Figure 2. Some anti-viral approved drugs used in clinical trials for the treatment of SARS-CoV-2.

The well-known mode of action for nucleoside analogues is through the triphosphate (TP) active form, which allows these analogues to act as competitive inhibitors of the viral DNA polymerase [36]. To become active, the free $\mathrm{OH}$ group undergoes three intracellular phosphorylation reaction that convert the nucleoside analogues into (TP) forms. Our newly synthesized compounds are nucleoside analogues that bear the free $\mathrm{OH}$ group, which helps them undergo phosphorylation inside the viral cell; however, further investigation into their mode of action must be performed.

Based on the above information, we applied our interest in pyrimidine-derived bioactive molecules to prepare new cyclic and acyclic nucleosides that incorporate 6-substitutedpyrimidine moieties to increase their biological activities.

\section{Results}

\subsection{Chemical Results}

The synthesis of pyrimidine nucleoside analogues was performed via the alkylation of silylated pyrimidine alkylation, according to Vorbrüggen and Niedballa's procedure [40-42]. First, 6-(2,4-dibromophenoxy methyl)-pyrimidine-2,4-dione 1 was prepared via the condensation of ethyl-4-(2,4-dibromophenoxy)-3-oxobutanoate with urea in the presence of sodium ethoxide [43-45]. Pyrimidine-2,4-dione 1 on reaction with hexamethyldisilazane (HMDS) [45], afforded Bis(trimethylsilyl) 2. which was then reacted with different acyclic sugar analogues, namely, 2-acetoxyethyl acetoxymethyl ether 
i, 2-(acetoxymethoxy)propane-1,3-diyldibenzoate ii and benzyloxymethyl acetate iii to produce the corresponding protected nucleoside analogues 3,4 , and 5 respectively. Dialkylation occurred when compound $\mathbf{2}$ interacted with benzyloxymethyl acetate iii, to offer dibenzoxymethyl derivative (6) [40,42]. The structures of all the newly prepared compounds were fully characterized by (Mass, ${ }^{1} \mathrm{H}-\mathrm{NMR}$ and ${ }^{13} \mathrm{C}-\mathrm{NMR}$ analysis). The ${ }^{1} \mathrm{H}-\mathrm{NMR}$ showing the disappearance of the $\mathrm{NH}$ proton, with the appearance of new signals in the range $\delta \approx 5.40-5.45 \mathrm{ppm}$ for $\mathrm{O}-\mathrm{CH}_{2}{ }^{*}-\mathrm{N}$, indicated the formation of acyclic analogues 3,4 and $5\left({ }^{13} \mathrm{C}-\mathrm{NMR}\right.$ appearance of oxymethyl $\mathrm{C}\left(\mathrm{O}-\mathrm{CH}_{2}{ }^{*}-\mathrm{Ph}\right)$ in the range of $71-72 \mathrm{ppm}$. For compound 6, where dialkylation occurred, the disappearance of $\mathrm{NH}$ was observed, and two new signals at $\delta \approx 5.32$ and $5.46 \mathrm{ppm}$ attributed to $2 \mathrm{H}^{*}$ of $\mathrm{O}^{*} \mathrm{CH}_{2} \mathrm{~N}^{1}$ and $2 \mathrm{H}^{*}$ of $\mathrm{O}^{*} \mathrm{CH}_{2} \mathrm{~N}^{3}$ appeared. ${ }^{13} \mathrm{C}-\mathrm{NMR}$ showed the appearance of the two oxymethyl carbon groups $\left(2^{*}\left(\mathrm{O}-\mathrm{CH}_{2}{ }^{*}-\mathrm{Ph}\right)\right.$ in the range $\left.\approx 71-73 \mathrm{ppm}\right)$

Protection removal for compounds 3 and $\mathbf{4}$ was achieved by splitting the ester blocking with an $\mathrm{MeOH} / \mathrm{NH}_{3}$ solution [46-49] to give $\mathbf{7}$ and $\mathbf{8}$ in a fairly moderate yield $(\approx 55$ to $80 \%$ ), respectively, as revealed in Scheme 1 . The ${ }^{1} \mathrm{H}-\mathrm{NMR}$ showed the appearance of the free $\mathrm{OH}$ protons in the range $\delta \approx 4.5-4.9 \mathrm{ppm}$.

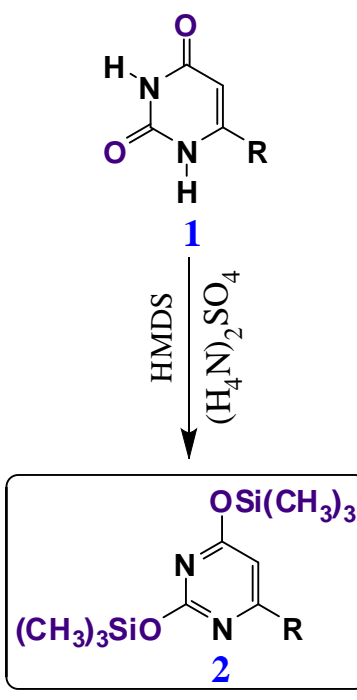

$\mathrm{HMDS}=\left[(\mathrm{CH} 3)_{3} \mathrm{Si}\right]_{2} \mathrm{NH}$<smiles>CCOc1ccc(Br)cc1Br</smiles>

$\mathrm{R}^{\prime}=\mathrm{PhCH}_{2}$ -

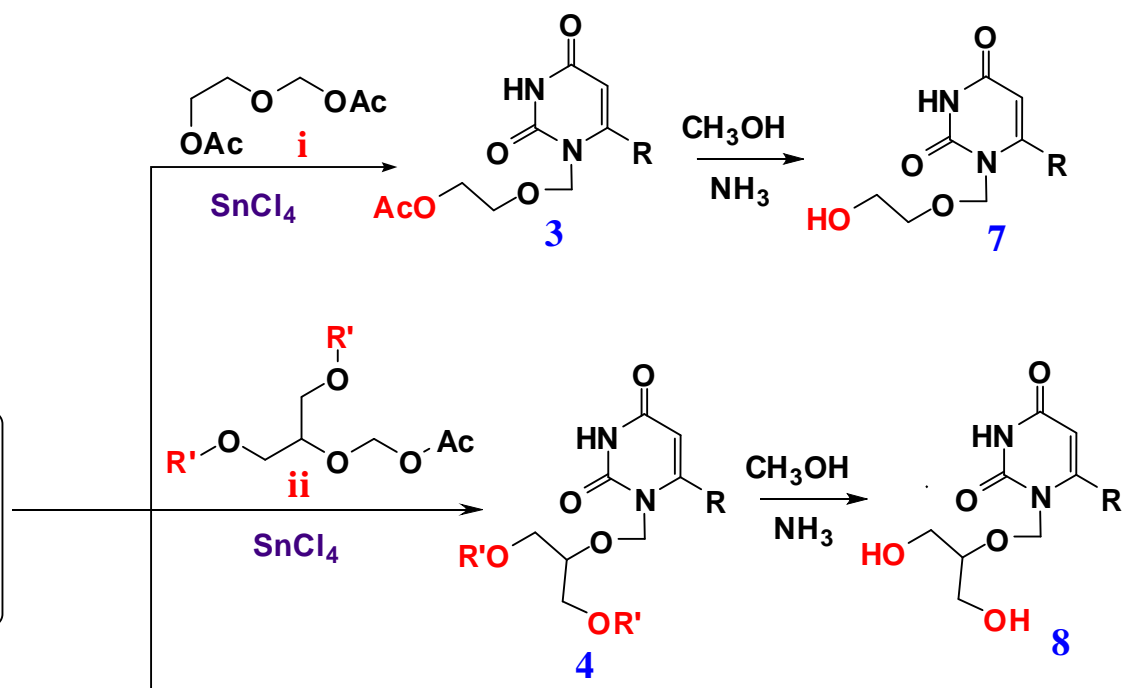

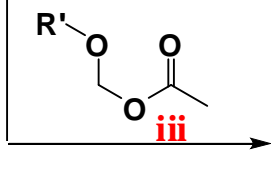$$
\mathrm{R}^{\prime} \mathrm{O}
$$<smiles>[R]OCOCn1c([18F])cc(=O)[nH]c1=O</smiles>

5<smiles>[R]OCOCn1c([R])cc(=O)n(COCO)c1=O</smiles>

6

Scheme 1. Synthesis of acyclic nucleosides (3-8).

Cyclic nucleosides (9-11) were prepared via the reaction of silyated pyrimidine 2 with various activated cyclic sugars, namely, 1-acetate-2,3,5-tri-0-benzoate- $\beta$-D-ribofuranose iv, 2deoxy-3,5-di-0-p-chlorobenzoyl-D-ribofuranosyl chloride $\mathbf{v}$ and 1-bromo-2,3,4-tetra-0-acetyl-ßD-glucopyranose vi as reported in [9,50,51], giving the protected nucleosides $\mathbf{9 ,} \mathbf{1 0}$ and $\mathbf{1 1}$ as a B-anomers. ${ }^{1} \mathrm{H}-\mathrm{NMR}$ showed a doublet signal in the range $\delta \approx 6.20-6.48 \mathrm{ppm}$, corresponding to the anomeric proton of a sugar moiety with a coupling constant $\left(\mathrm{J}_{1,2}=9.10-9.50 \mathrm{~Hz}\right)$ that was attributed to the diaxial orientation of $\mathrm{H}-1$ and $\mathrm{H}-2$ protons, indicating the presence of a B-configuration. Compounds $\mathbf{9 , 1 0}$ and $\mathbf{1 1}$ were deprotected by using an $\mathrm{MeOH} / \mathrm{NH}_{3}$ solution at room temperature [52] to give the compounds 12,13 , and 14, respectively, as revealed in Scheme 2. The ${ }^{1} \mathrm{H}-\mathrm{NMR}$ showed the appearance of the free $\mathrm{OH}$ protons, new signals in the 
range $\delta \approx 3.75-4.6 \mathrm{ppm}$ and the ${ }^{13} \mathrm{C}-\mathrm{NMR}$ showed the appearance of six carbons from the cyclic sugar moiety in the range $\approx 62-98 \mathrm{ppm}$ ).

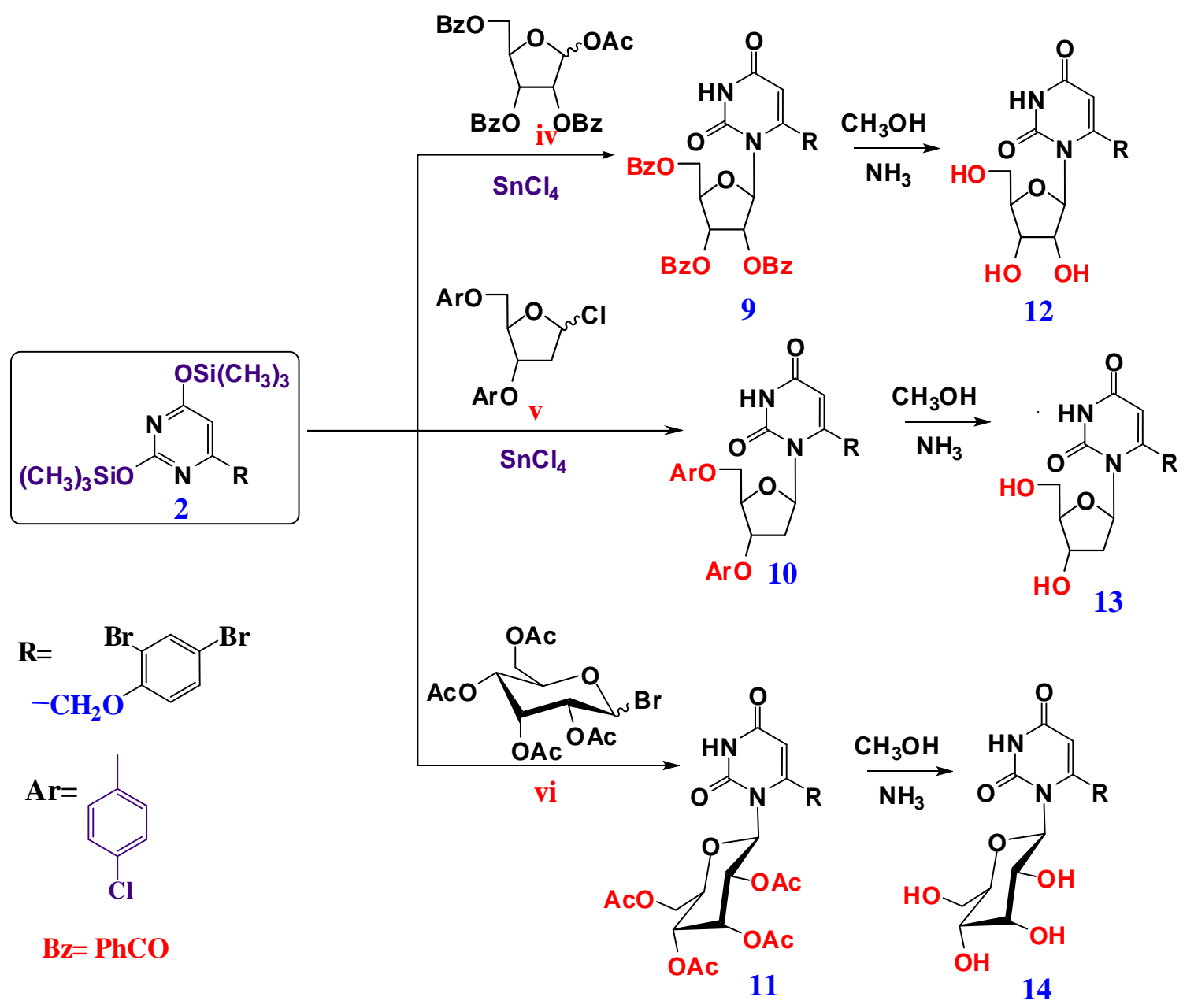

Scheme 2. Synthesis of cyclic nucleosides (9-14).

\subsection{Biological Results}

Antiherpetic Activity of the Synthesized Compounds

Cytopathic effect (CPE) inhibition was evaluated for the 12 synthesized compounds at different concentrations $(6,12,18,24,30,36,42,48,54,60,66,72,78$ and $84 \mu \mathrm{g} / \mathrm{mL})$ against the HSV-1 KOS strain. ACV was included as a control in each assay. The percentage values for CPE inhibition were reported in (Table 1).

From Table 1, we can see that the tested compounds exhibited varied antiherpetic activity compared to that of ACV, yet $6 \mu \mathrm{g} / \mathrm{mL}$ of all compounds and ACV could not prevent CPE presentation. A concentration of $12 \mu \mathrm{g} / \mathrm{mL}$ also could not prevent CPE except for compounds 4, 6, and 8, which gave a CPE inhibition of 14,30 and $32 \%$, respectively. At a concentration of $36 \mu \mathrm{g} / \mathrm{mL}$, total prevention of viral CPE presentation was induced in compounds 6 and 8, while the control drug ACV needed a higher concentration $(42 \mu \mathrm{g} / \mathrm{mL})$ to produce the same effect. The results clearly indicated that two synthetic compounds (6 and 8) showed higher antiviral activity than did ACV. Compound 4 also produced total prevention of viral CPE presentation at the same concentration as ACV $(42 \mu \mathrm{g} / \mathrm{mL})$. Antiviral activity was also expressed as the $\mathrm{EC}_{50}$, and the results are reported in Figure 3. 
Table 1. Inhibition of HSV-1-related CPE using different concentrations of tested compounds and a standard drug (ACV).

\begin{tabular}{|c|c|c|c|c|c|c|c|c|c|c|c|c|c|}
\hline \multirow{2}{*}{ 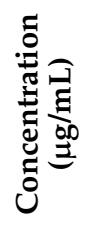 } & \multicolumn{13}{|c|}{ CPE Inhibition (\%) } \\
\hline & $\stackrel{*}{z}$ & ? & $\begin{array}{l}* \\
\forall \\
\dot{\Xi} \\
\dot{0}\end{array}$ & 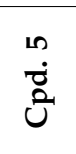 & $\begin{array}{l}\text { * } \\
\text { نें } \\
\dot{0}\end{array}$ & ن̃ & $\begin{array}{l}* \\
\infty \\
\dot{0} \\
\tilde{0}\end{array}$ & $\begin{array}{l}a \\
\dot{0}\end{array}$ & $\begin{array}{l}0 \\
\text { نें }\end{array}$ & $\begin{array}{l}F \\
\dot{0} \\
0\end{array}$ & $\begin{array}{l}\stackrel{*}{\sim} \\
\stackrel{\sim}{*} \\
\stackrel{0}{2}\end{array}$ & $\begin{array}{l}\stackrel{0}{0} \\
\overrightarrow{0}\end{array}$ & 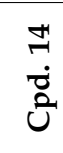 \\
\hline 6 & 0 & 0 & 0 & 0 & 0 & 0 & 0 & 0 & 0 & 0 & 0 & 0 & 0 \\
\hline 12 & 29 & 0 & 14 & 0 & 30 & 0 & 32 & 0 & 0 & 0 & 0 & 0 & 0 \\
\hline 18 & 50 & 12 & 22 & 15 & 45 & 0 & 42 & 0 & 0 & 0 & 0 & 0 & 0 \\
\hline 24 & 70 & 28 & 42 & 28 & 65 & 10 & 72 & 0 & 10 & 0 & 32 & 0 & 0 \\
\hline 30 & 77 & 34 & 62 & 40 & 80 & 16 & 80 & 22 & 20 & 18 & 44 & 22 & 18 \\
\hline 36 & 92 & 38 & 70 & 65 & 100 & 20 & 100 & 28 & 32 & 22 & 75 & 34 & 28 \\
\hline 42 & 100 & 55 & 100 & 82 & & 26 & & 34 & 50 & 26 & 86 & 45 & 36 \\
\hline 48 & & 77 & & 100 & & 66 & & 38 & 82 & 34 & 100 & 52 & 46 \\
\hline 54 & & 80 & & & & 74 & & 47 & 100 & 46 & & 66 & 58 \\
\hline 66 & & & & & & 100 & & 88 & & 74 & & 77 & 82 \\
\hline 72 & & & & & & & & 100 & & 78 & & 82 & 100 \\
\hline 78 & & & & & & & & & & 85 & & 100 & \\
\hline 84 & & & & & & & & & & 100 & & & \\
\hline
\end{tabular}

* Most potent compounds. 


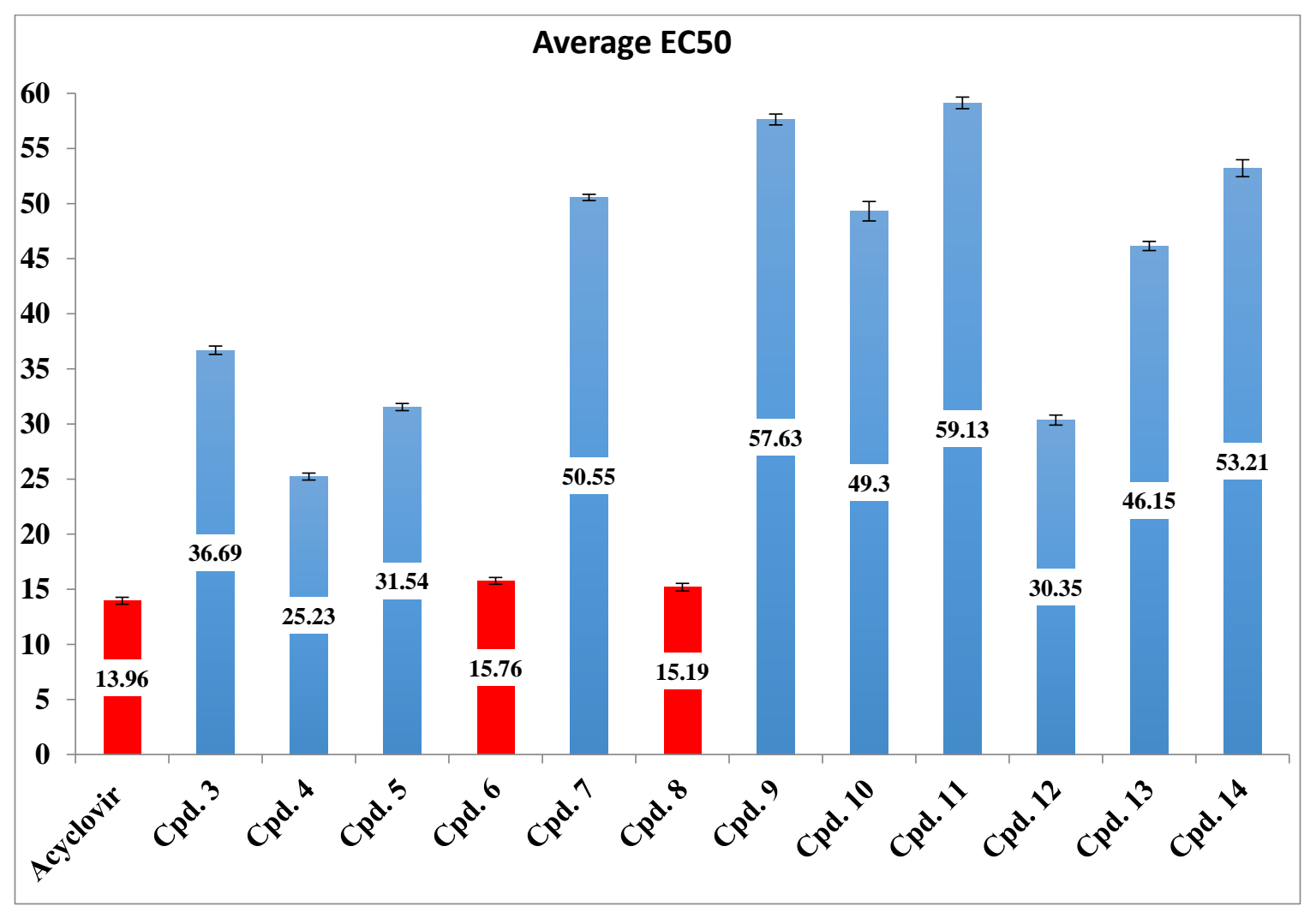

Figure 3. Inhibitory effect of tested compounds and ACV represented by average $\mathrm{EC}_{50}$.

According to statistical analysis, it was found that compounds 4, 6 and 8 were active against HSV-1 with an average $\mathrm{EC}_{50}$ of 25.23, 15.76 and 15.1, respectively, which were close to that of ACV (13.96). There was also an insignificant difference $(p>0.05)$ between their $\mathrm{EC}_{50}$ values compared to that of $\mathrm{ACV}$, but there was a significant difference $(p<0.05)$ between them and those of other compounds. Some compounds $(3,5$ and 12) showed moderate activity 1 with an $\mathrm{EC}_{50}$ of $36.69,31.54$ and 30.35 , respectively. The other compounds (7, 9, 10, 11, 13 and 14) showed low activity. The strongest antiviral synthesized compounds were chosen, and the antiviral assay experiment was repeated three times. The results are reported in Table 2.

Table 2. Inhibition of HSV-1-related CPE by using different concentrations of the most potent tested compounds and a standard drug (ACV).

\begin{tabular}{ccccc}
\hline \multirow{2}{*}{$\begin{array}{c}\text { Concentration } \\
(\mu \mathrm{g} / \mathrm{mL})\end{array}$} & Compound 4 & Compound 6 & Compound 8 & ACV \\
\cline { 2 - 5 } & & \multicolumn{2}{c}{ CPE Inhibition $\mathbf{( \% )}$ Mean $\pm \mathbf{S E}$} & \\
\hline 6 & $0.00 \pm 0.00$ & $0.00 \pm 0.00$ & $0.00 \pm 0.00$ & $0.00 \pm 0.00$ \\
\hline 12 & $14.25 \pm 3.75$ & $30.30 \pm 3.40$ & $31.95 \pm 2.75$ & $29.00 \pm 3.00$ \\
\hline 18 & $22.35 \pm 2.25$ & $45.90 \pm 3.40$ & $41.25 \pm 4.05$ & $49.80 \pm 3.40$ \\
\hline 24 & $42.35 \pm 1.85$ & $65.15 \pm 1.75$ & $72.25 \pm 2.05$ & $70.45 \pm 2.75$ \\
\hline 32 & $62.00 \pm 5.00$ & $80.40 \pm 10.00$ & $80.00 \pm 10.00$ & $77.65 \pm 1.75$ \\
\hline 36 & $75.75 \pm 9.85$ & $99.00 \pm 1.00$ & $99.00 \pm 1.00$ & $92.50 \pm 4.50$ \\
\hline 42 & $99.50 \pm 0.50$ & & & $99.50 \pm 0.50$ \\
\hline
\end{tabular}




\section{Discussion}

From the abovementioned results, we can conclude that the activity of acyclic nucleosides predominated over that of the cyclic forms. In fact, the acyclics 4,6 and 8 showed the highest activity. Compound 4 , the protected form of compound 8 containing $\mathrm{N}$-substitution-bearing dibenzyloxymethyl displayed the lowest activity $(25.23 \%)$, and removing one benzyloxymethyl group from compound 6 increased its activity (15.76\%); these two findings indicated that the addition of a bulky group in an acyclic moiety reduced its activity. The highest activity, given by compound $8(15.19 \%)$, occurred after the hydrolysis of a benzoyl group into a free hydroxyl group, indicating the importance of the hydrophilicity the free $\mathrm{OH}$ group provided to the activity. Compound $\mathbf{8}$ was similar to $\mathrm{ACV}$ in its free amidic moiety and free-OH acyclic sugar. On the other hand, the cyclic form carrying the $O$-acetyl- $\beta$ - $D$-glucopyranosyl moiety, as in compound $\mathbf{1 1}$ showed the lowest activity $(59.13 \%)$ compared to $\mathrm{ACV}$, indicating that the bulkiness of the $N^{1}$-substitution decreased activity as shown in Figure 4.

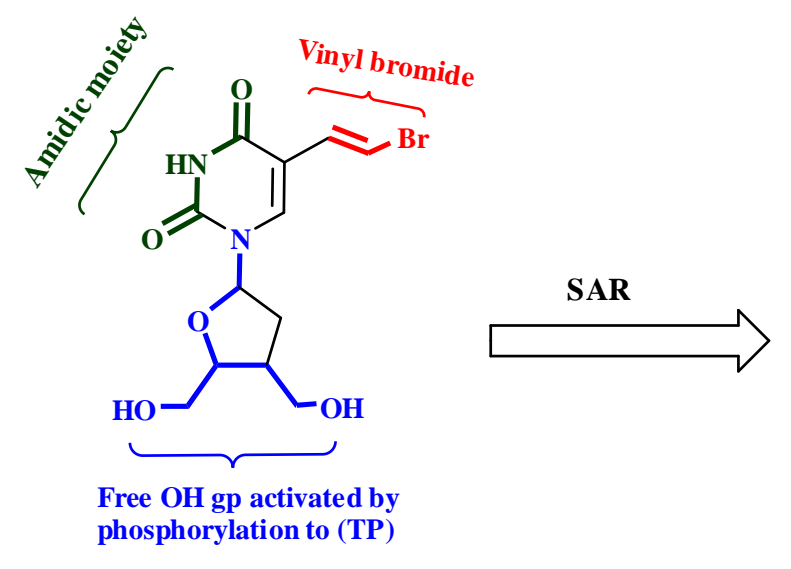

\section{BVDU}
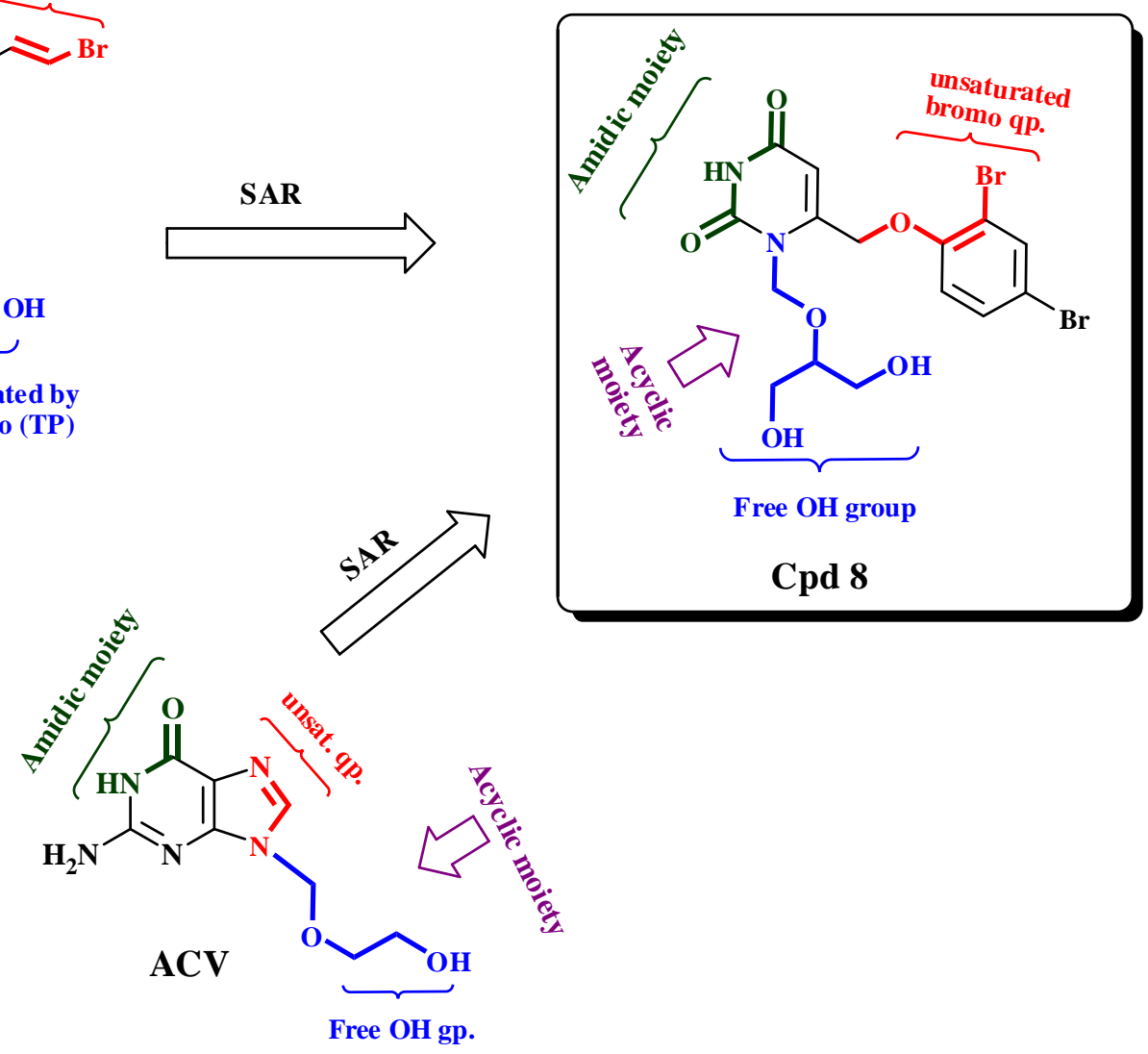

Figure 4. SAR relation between active compounds and reference drug (Acyclovir).

In this study, some of the synthetic compounds, uracil nucleoside analogues, showed very good antiherpetic activity almost equal to that of ACV as shown in Figure 2 and Table 2. Uracil nucleosides are one of the two main groups that inhibits the polymerase [10], which has been studied over many years and represents a highly important target for antiherpetic drugs $[53,54]$. Another example of uracil nucleoside analogues with a significant antiherpetic activity was presented by Mansour and co-workers (1994). A thiouridine derivative was effective against both HSV-1 and HSV-2 [16,55].

Our results are very promising as these compounds could work to overcome the current resistance to antiherpetic drugs already in use. ACV and related nucleoside analogues have been the gold-standard molecules for treating HSV infections during the 
past decades [1]; however, the long-term use of antiherpetic drugs has led to selective strain resistance [56-58]. These HSV mutants can lead to more severe and chronic infections in immunocompromised patients [1] and even a significant morbidity [56]. For all those reasons, HSV resistance is presented as a major clinical problem for immunocompromised patients [1]. The fact that the numbers of transplant and cancer patients are escalating makes it obvious why the emergence of drug-resistant HSV infections is now a common problem [1]. There are several resistance mechanisms of HSV to ACV 2 ; (a) decreased viral TK production, (b) complete deficiency of viral TK activity, and (c) altered substrate specificity of the viral TK protein and DNA polymerase [7].

Resistance to another nucleoside analogue (VCV, the prodrug of $\mathrm{ACV}$ ) has also been reported, and the mechanism of resistance is identical to that of ACV [59]. PCV and its prodrug FCV, which are also among the gold-standard agents for the prophylaxis and treatment of HSV-1, have been reported to induce resistance in HSV-1. FOS is an antiviral drug that can overcome HSV-developed ACV resistance [60], but it causes nephrotoxicity, which is a major drawback that limits its clinical use [61,62]. Moreover, some mutants with double resistance to both ACV and FOS can also occur [56]. Another drug that is able to overcome HSV resistance is CDV, an acyclic nucleoside phosphonate, that is reported to be effective against ACV and FOS-resistant HSV in immunocompromised patients [63]. However, it is also nephrotoxic [64], and mutations that have cross-resistance to ACV and FOS have reduced susceptibility to it [65].

Because polymerase target binding sites are highly conserved among virus families [10], nucleoside analogue inhibitors possess a relatively high barrier to viral resistance, meaning that the nucleoside analogues presented in our study represent a very good approach for the treatment of drug-resistant HSV-1.

\section{Materials and Methods}

\subsection{Chemistry}

All reagents and solvents were purchased from Merck (Darmstadt, Germany) and used without further purification. All melting points were uncorrected and measured using Electro-thermal IA 9100 apparatus (Shimadzu, Kyoto, Japan). The NMR spectra were recorded on Bruker AMX400 and Bruker Current AV400 Data spectrometer $(400 \mathrm{MHz}$ for ${ }^{1} \mathrm{H}, 100.6 \mathrm{MHz}$ for ${ }^{13} \mathrm{C}$ ), Bruker BioSpin $\mathrm{GmbH}$, Rheinstetten, Germany. Spectra and chemical shifts $(\delta)$ were expressed as ppm against TMS as an internal reference. ESI mass spectra using a Finnigan Thermo Quest MAT 95XL spectrometer and FAB high-resolution (HR) mass spectra using a VG Analytical 70-250S spectrometer (Palmer, Hampden, MA, USA) were conducted using an MCA method with polyethylene glycol as a support. The reactions were monitored by thin layer chromatography (TLC) analysis using silica gel (60 F254)-coated aluminum plates (Merck), which were visualized by UV irradiation $(254 \mathrm{~nm})$ and iodine vapors. Column chromatography was performed using 60-120 mesh silica gel. All reactions were carried out under the influence of dry nitrogen.

4.1.1. Preparation of 4-((2,4-Dibromophenoxy)methyl)-2,6-bis (trimethylsilyloxy) pyrimidine 2

Uracil 1 (3.8 g, $10 \mathrm{mmol}),\left(\mathrm{NH}_{4}\right)_{2} \mathrm{SO}_{4}(10 \mathrm{~g}, 7.5 \mathrm{mmol})$ in $\left.\left[\left(\mathrm{CH}_{3}\right)_{3} \mathrm{Si}\right]_{2} \mathrm{NH}\right)(\mathrm{HMDS})$ (50 mL, $2.25 \mathrm{mmol}$ ) was refluxed with stirring for $4 \mathrm{~h}$. The reaction solvent was evaporated under reduced pressure to give compound 2 .

\subsubsection{General Procedure for Preparation of Acyclic and Cyclic Nucleosides}

A mixture of (10 mmol) acylated reagents was carried out in dry acetonitrile $(30 \mathrm{~mL})$, and these consisted of $\mathbf{i}$, acyclic 2-acetoxyethyl acetoxymethyl ether; $\mathbf{i i}$, 2-(acetoxymethoxy) propane-1,3-diyldibenzoate; iii, benzyloxymethyl acetate; iv, cyclic 1-acetate-2,3,5-tri-Obenzoate- $\beta$ - $D$-ribofuranose; v, 2-deoxy-3,5-di-O-p-chlorobenzoyl- $D$-ribofuranosyl chloride; and vi, 1-bromo-2,3,4-tetra-O-acetyl- $\beta$ - $D$-glucopyranose. $\mathrm{SnCl}_{4}(2 \mathrm{~mL})$ was added to the residue of $2(10 \mathrm{mmol})$ and stirred at $-30^{\circ} \mathrm{C}$ for $24 \mathrm{~h}$. The reaction mixture was treated with 
dry pyridine $(4 \mathrm{~mL})$, left until an inorganic residue formed then filtered off. The filtrate was diluted with $\mathrm{CHCl}_{3}(40 \mathrm{~mL})$, washed with a saturated solution of $\mathrm{NaHCO}_{3}(50 \mathrm{~mL})$, then a $1 \mathrm{~N}$ solution of $\mathrm{HCl}(50 \mathrm{~mL})$, followed by brine $(50 \mathrm{~mL})$ and $\mathrm{H}_{2} \mathrm{O}(50 \mathrm{~mL})$ successively. The mixture was dried over anhydrous $\mathrm{Na}_{2} \mathrm{SO}_{4}$ and concentrated until drying under reduced pressure. The residue was separated by silica-gel column chromatography (graduated mixture of $\mathrm{CH}_{3} \mathrm{COOEt}$ and petroleum ether ratio 9:1) to give acyclic nucleosides (3-6) and cyclic nucleosides (9-11) (Supplementary Materials).

1-[(2-Acetoxyethoxy)methyl]-6-(2,4-dibromophenoxymethyl)uracil (3)

Yield: $1.8 \mathrm{~g}(70 \%)$, m.p. $170-172{ }^{\circ} \mathrm{C} .{ }^{1} \mathrm{H}-\mathrm{NMR}\left(\mathrm{DMSO}_{\mathrm{d}}, 400 \mathrm{MHz}\right): \delta 2.33(\mathrm{~s}, 3 \mathrm{H}$, $\left.\mathrm{CH}_{3} \mathrm{C}=\mathrm{O}\right) 3.5-4.50\left(\mathrm{~m}, 6 \mathrm{H}, 3^{*}\left(\mathrm{CH}_{2}\right), \mathrm{O}-\mathrm{CH}_{2}\right), 5.41\left(\mathrm{~s}, 2 \mathrm{H}, \mathrm{OCH}_{2} \mathrm{~N}^{1}\right), 5.62(\mathrm{~s}, 1 \mathrm{H}, \mathrm{CH}$ uracil $)$, 7.10-8 (m, 3H,ArH a s,1H, $\left.{ }^{*} \mathrm{NH}\right) .{ }^{13} \mathrm{C}-\mathrm{NMR}\left(\mathrm{DMSO}_{6}, 100 \mathrm{MHz}\right): \delta 20.5,63.2,65.0,66.7$, 72.1, 100.7, 115.9, 116.0, 122.9, 126.1, 128.6, 129.9, 151.5, 151.9, 152.0, 162.7, 170.6. MS (EI) $m / z: 405.02$ [M-AcOCH$\left.{ }_{2} \mathrm{CH}_{2}\right]^{+}$. Anal. Calcd for $\mathrm{C}_{16} \mathrm{H}_{16} \mathrm{Br}_{2} \mathrm{~N}_{2} \mathrm{O}_{6}: \mathrm{C}, 39.05 ; \mathrm{H}, 3.28 ; \mathrm{N}, 5.69$; Found $\mathrm{C}, 39.02 ; \mathrm{H}, 3.31 ; \mathrm{N}, 5.65$.

2-[(6-(2,4-dibromophenoxymethyl)-2,4-dioxo-1-pyrimidinyl)methoxy]-1,3-propanediyl dibenzoate (4)

Yield: $4.3 \mathrm{~g}$ (73\%), m.p. $163-165^{\circ} \mathrm{C} .{ }^{1} \mathrm{H}-\mathrm{NMR}\left(\mathrm{DMSO}_{\mathrm{d}}, 400 \mathrm{MHz}\right): \delta 3.8-4.50$ (m, $\left.5 \mathrm{H}, 2 * \mathrm{CH}_{2}, \mathrm{CH}\right), 5.11\left(\mathrm{~s}, 2 \mathrm{H}, \mathrm{CH}_{2}\right.$, phenoxy), $5.43\left(\mathrm{~s}, 2 \mathrm{H}, \mathrm{OCH}_{2} \mathrm{~N}\right), 5.62(\mathrm{~s}, 1 \mathrm{H}, \mathrm{CH}$ uracil), 6.90-8.03 (m, 13H, Ar-H and s,1H,NH8). ${ }^{13} \mathrm{C}-\mathrm{NMR}$ (DMSO-d $\left.6,100 \mathrm{MHz}\right): \delta 64.1,64.8,71.3$, 74.3, 100.6, 115.6, 122.8, 125.9, 128.4, 129.0, 129.5, 129.8, 133.8, 151.3, 151.7, 152.2, 162.5, 165.8 MS (EI) $m / z: 688.2\left[\mathrm{M}^{+}\right]$. Anal. Calcd for $\mathrm{C}_{29} \mathrm{H}_{24} \mathrm{Br}_{2} \mathrm{~N}_{2} \mathrm{O}_{8}: \mathrm{C}, 58.11 ; \mathrm{H}, 4.04 ; \mathrm{N}, 4.67$. Found C, 58.24; $\mathrm{H}, 4.13 ; \mathrm{N}, 4.53$.

1-(Benzyloxymethyl)-6-(2,4-dibromophenoxy methyl) uracil (5)

Yield: $2.8 \mathrm{~g}(69 \%)$, m.p. $133-135{ }^{\circ} \mathrm{C} .{ }^{1} \mathrm{H}-\mathrm{NMR}\left(\mathrm{DMSO}^{-} \mathrm{d}_{6}, 400 \mathrm{MHz}\right): \delta 4.62(\mathrm{~s}, 2 \mathrm{H}$, $\left.\mathrm{CH}_{2} \mathrm{Ph}\right), 5.25\left(\mathrm{~s}, 2 \mathrm{H}, \mathrm{CH}_{2}\right.$, phenoxy), $5.45\left(\mathrm{~s}, 2 \mathrm{H}, \mathrm{OCH}_{2} \mathrm{~N}\right), 5.81(\mathrm{~s}, 1 \mathrm{H}, \mathrm{CH}$ uracil), 7.28-7.81(m, $8 \mathrm{H}, \mathrm{Ar}-\mathrm{H}), 8.25\left(\mathrm{~s}, 1 \mathrm{H},{ }^{*} \mathrm{NH}\right) .{ }^{13} \mathrm{C}$ NMR (DMSO-d $\left.{ }_{6}, 100 \mathrm{MHZ}\right): \delta 64.1,70.3,71.5,100.6,115.6$, 122.6, 125.7, 127.0, 127.7, 128.1, 128.2, 129.5, 137.3, 150.9, 151.5, 151.6, 158.8, 162.5, 165.8. MS (EI) $\mathrm{m} / z$ : $402.2\left[\mathrm{M}-\mathrm{CH}_{2} \mathrm{Ph}\right]^{+}$. Anal. Calcd for $\mathrm{C}_{19} \mathrm{H}_{16} \mathrm{Br}_{2} \mathrm{~N}_{2} \mathrm{O}_{4}: \mathrm{C}, 45.99 ; \mathrm{H}, 3.25 ; \mathrm{N}, 5.65$. Found C, 45.96: H, 3.29; N, 5.61.

1,3-di(Benzyloxymethyl)-6-(2,4-dibromophenoxy methyl) uracil (6)

Yield: $3 \mathrm{~g}(58 \%)$, m.p. $148-150{ }^{\circ} \mathrm{C} .{ }^{1} \mathrm{H}-\mathrm{NMR}$ (DMSO-d $\left.{ }_{6}, 400 \mathrm{MHz}\right): \delta 4.43,4.45(2 \mathrm{~s}, 4 \mathrm{H}$, $\left.2{ }^{*} \mathrm{CH}_{2}{ }^{*} \mathrm{Ph}\right), 5.24\left(\mathrm{~s}, 2 \mathrm{H}, \mathrm{CH}_{2}\right.$, phenoxy), $5.32\left(\mathrm{~s}, 2 \mathrm{H}, \mathrm{OCH}_{2} \mathrm{~N}^{1}\right), 5.47\left(\mathrm{~s}, 2 \mathrm{H}_{1} \mathrm{OCH}_{2} \mathrm{~N}^{3}\right), 5.81(\mathrm{~s}$, $1 \mathrm{H}, \mathrm{CH}$ uracil), $7.25-7.67(\mathrm{~m}, 13 \mathrm{H}, \mathrm{Ar}-\mathrm{H}), 8.01\left(\mathrm{~s}, 1 \mathrm{H},{ }^{*} \mathrm{NH}\right) .{ }^{13} \mathrm{C}$ NMR (DMSO-d $\left.6,100 \mathrm{MHz}\right)$ :

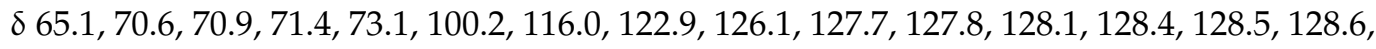
129.9, 137.7, 138.8, 150.8, 151.8, 152.2, 161.6. MS (EI) $\mathrm{m} / z: 527.3\left[\mathrm{M}^{+}\right]$. Anal. Calcd for $\mathrm{C}_{27} \mathrm{H}_{24} \mathrm{Br}_{2} \mathrm{~N}_{2} \mathrm{O}_{5}: \mathrm{C}, 58.11 ; \mathrm{H}, 4.04 ; \mathrm{N}$, 4.67. Found $\mathrm{C}, 58.24 ; \mathrm{H}, 4.13 ; \mathrm{N}, 4.53$.

1-(2,3,5-Tri-O-benzoyl-ß-D-ribofuranosyl)-6-(2,4-dibromophenoxy methyl) uracil (9)

Yield: 4.5 g(62\%), m.p. $117-119^{\circ} \mathrm{C} .{ }^{1} \mathrm{H}-\mathrm{NMR}$ (DMSO-d $\left.{ }_{6}, 400 \mathrm{MHz}\right): \delta 4.31-4.40$ (m, 2H, $\left.\mathrm{H}-5^{\prime}, 5^{\prime \prime}\right)$ 4.51-4.60 (m, 1H,H-4'), 4.91 (s,2H, $\mathrm{CH}_{2}$, phenoxy), 5.71 (s,1H,CH uracil), 5.90-6.11 $\left(\mathrm{m}, 2 \mathrm{H}, \mathrm{H}-2^{\prime}, \mathrm{H}-3^{\prime}\right), 6.4\left(\mathrm{~d}, 1 \mathrm{H}, \mathrm{j}=9.10 \mathrm{~Hz}, \mathrm{H}-1^{\prime}\right), 7.10-7.98(\mathrm{~m}, 18 \mathrm{H}, \mathrm{Ar}-\mathrm{H}), 8.21\left(\mathrm{~s}, 1 \mathrm{H},{ }^{*} \mathrm{NH}\right)$. ${ }^{13}$ C-NMR (DMSO-d 6,100 MHz): $\delta$ 63.7, 66.2, 70.7, 73.8, 74.1, 74.5, 78.2, 98.0, 102.9, 115.7, 116.2, 123.0, 125.9, 128.6, 128.8, 128.9, 129.1, 129.2, 129.5, 129.6, 129.7, 129.9, 133.7, 134.0, 134.1, 150.2, 150.9, 151.8, 162.5, 164.9, 165.1, 165.8. MS (EI) $m / z: 730.2\left[\mathrm{M}^{+}\right]$. Anal. Calcd for $\mathrm{C}_{37} \mathrm{H}_{28} \mathrm{Br}_{2} \mathrm{~N}_{2} \mathrm{O}_{10}$ : C, 58.11; H, 4.04; N, 4.67. Found C, 58.24; H, 4.13; N, 4.53.

((2R,3S,5R)-3-(4-chlorobenzoloxy)-5-(6-((2,4-dibromophenoxy)methyl)-2,4-dioxo-3,4dihydropyrimidin-1-(2H)-yl)tetrahydrofuran-2-yl)methyl-4-chlorobenzoate (10)

Yield: $4.5 \mathrm{~g}(62 \%)$, m.p. $117-119{ }^{\circ} \mathrm{C} .{ }^{1} \mathrm{H}-\mathrm{NMR}\left(\mathrm{DMSO}^{\mathrm{d}}{ }_{6}, 400 \mathrm{MHz}\right): \delta 4.31-4.40$ $\left(\mathrm{m}, 2 \mathrm{H}, \mathrm{H}-5^{\prime}, 5^{\prime \prime}\right) 4.51-4.60\left(\mathrm{~m}, 1 \mathrm{H}, \mathrm{H}-4^{\prime}\right), 4.91\left(\mathrm{~s}, 2 \mathrm{H}, \mathrm{CH}_{2}\right.$, phenoxy), $5.71(\mathrm{~s}, 1 \mathrm{H}, \mathrm{CH}$ uracil), 
5.90-6.11 (m, 2H,H-2',H-3'), 6.4(d, 1H,j = 9.10 Hz, H-1'), 7.10-7.98 (m, 18H, Ar-H), 10.91(br $\mathrm{s}, 1 \mathrm{H}, \mathrm{NH}) .{ }^{13} \mathrm{C}$ NMR (DMSO-d $\left.6,100 \mathrm{MHZ}\right): \delta 34.8,66.4,67.6,74.9,75.6,80.3,82.3,102.9$, $115.7,128.5,129.1,129.2,129.3,129.4,129.8,129.9,130.4,130.6,131.0,131.1,131.3,131.4$, 131.5, 138.6, 150.4, 150.8, 151.1, 162.8, 163.0, 164.9, 165.0. MS (EI) m/z: 730.2 [M $\left.{ }^{+}\right]$. Anal. Calcd for $\mathrm{C}_{37} \mathrm{H}_{28} \mathrm{Br}_{2} \mathrm{~N}_{2} \mathrm{O}_{10}$ : C, 58.11; $\mathrm{H}, 4.04 ; \mathrm{N}, 4.67$. Found C, 58.24; $\mathrm{H}, 4.13 ; \mathrm{N}, 4.53$.

1-(2,3,4,6-Tetra-O-acetyl- $\beta$ - $D$-glucopyranosyl)-6-(2,4-dibromophenoxymethyl) uracil (11)

Yield: $4.3 \mathrm{~g}(63 \%)$, m.p. $140-142{ }^{\circ} \mathrm{C} .{ }^{1} \mathrm{H}-\mathrm{NMR}\left(\mathrm{DMSO}-\mathrm{d}_{6}, 400 \mathrm{MHz}\right): \delta 1.82-2.12(4 \mathrm{~s}$, $\left.12 \mathrm{H}, 4 \mathrm{COCH}_{3}\right), 3.32\left(\mathrm{~m}, 1 \mathrm{H}, \mathrm{H}-2^{\prime}\right), 5.62(\mathrm{~s}, 1 \mathrm{H}, \mathrm{CH}$ uracil $), 6.21\left(\mathrm{~d}, 1 \mathrm{H}, \mathrm{J} 1,2=9.51 \mathrm{~Hz}, \mathrm{H}-1^{\prime}\right)$, 7.10-7.82 (m, 3H, Ar-H), 10.92 (br s, 1H,NH). ${ }^{13} \mathrm{C}-\mathrm{NMR}$ (DMSO-d $6,100 \mathrm{MHz}$ ): $\delta 15.4,20.1$, 20.4, 20.6, 62.0, 65.2, 65.5, 67.8, 68.0, 68.2, 73.0, 77.7, 79.5, 96.6, 99.2, 115.6, 122.8, 125.8, 149.7, 151.6, 152.2, 162.2, 162.6, 169.2, 170.1. MS (EI) $m / z: 706.2\left[\mathrm{M}^{+}\right]$. Anal. Calcd for $\mathrm{C}_{25} \mathrm{H}_{26} \mathrm{Br}_{2} \mathrm{~N}_{2} \mathrm{O}_{12}: \mathrm{C}, 42.51 ; \mathrm{H}, 3.71 ; \mathrm{N}, 3.97$. Found $\mathrm{C}, 42.64 ; \mathrm{H}, 3.63 ; \mathrm{N}, 3.83$.

\subsubsection{General Procedure for De-Protection of Nucleosides to Prepare $(\mathbf{7}, \mathbf{8}, \mathbf{1 2}-\mathbf{1 4})$}

Protected nucleosides (3-5, 9-11) (10 mmol) were dissolved, individually, in $\mathrm{MeOH}$ $(20 \mathrm{~mL})$ with $\mathrm{NH}_{3}(3 \mathrm{~mL})$ and stirred for $48 \mathrm{~h}$ at room temperature. The solution was then concentrated to drying, under reduced pressure, and the resulting residue from $\mathrm{MeOH}$ was recrystallized to give unprotected nucleosides $(\mathbf{7}, \mathbf{8}, \mathbf{1 2}-\mathbf{1 4})$.

1-(2-Hydroxyethoxy methyl)-6-(2,4-dibromophenoxy methyl) uracil (7)

Yield: $2.8 \mathrm{~g}(81 \%)$, m.p. $222-224{ }^{\circ} \mathrm{C} .{ }^{1} \mathrm{H}-\mathrm{NMR}\left(\mathrm{DMSO}-\mathrm{d}_{6}, 400 \mathrm{MHz}\right): \delta 3.71,3.77$ $\left(2 \mathrm{t}, 4 \mathrm{H}, \mathrm{HOCH}_{2}{ }^{*} \mathrm{CH}_{2}{ }^{*} \mathrm{O}\right), 4.91\left(\mathrm{~s}, 1 \mathrm{H}, \mathrm{OH}^{*}\right), 5.52\left(\mathrm{~s}, 2 \mathrm{H}, \mathrm{Ph}-\mathrm{CH}_{2}{ }^{*}\right), 5.54\left(\mathrm{~s}, 2 \mathrm{H}, \mathrm{OCH}_{2} \mathrm{~N}\right), 6.14$ (s, 1H,C-5-H uracil), 7.41-7.81 (m, 3H,Ar-H), 8.11 (s, 1H,NH). ${ }^{13}$ C-NMR (DMSO-d $\left.6,100 \mathrm{MHz}\right)$ : $\delta 60.3,60.5,70.2,80.8,100.5,116.0,122.9,126.0,128.6,129.9,151.7,151.1,152.8,162.7$. MS (EI) $m / z$ : $450.07\left[\mathrm{M}^{+}\right]$. Anal. Calcd for $\mathrm{C}_{14} \mathrm{H}_{14} \mathrm{Br}_{2} \mathrm{~N}_{2} \mathrm{O}_{5}: \mathrm{C}, 37.36 ; \mathrm{H}, 3.14 ; \mathrm{N}, 6.22$. Found C,37.38; H,3.26; N, 6.19.

1-[2-Hydroxy-1-(hydroxyl methyl) ethoxymethyl]-6-(2,4-dibromo phenoxymethyl) uracil (8)

Yield: $3.3 \mathrm{~g}$ (83\%), m.p. $188-190{ }^{\circ} \mathrm{C} .{ }^{1} \mathrm{H}-\mathrm{NMR}$ (DMSO-d $\left.6,400 \mathrm{MHz}\right): \delta 3.41-3.57$ (m, $\left.5 \mathrm{H}, 2 * \mathrm{CH}_{2}, \mathrm{CH}\right), 4.85\left(\mathrm{~m}, 2 \mathrm{H}, \mathrm{OH}^{*}\right), 5.51$ (s, 2H, $\mathrm{CH}_{2}$ phenoxy), 5.61(s, 2H, $\left.\mathrm{OCH}_{2} \mathrm{~N}\right), 5.87$ (s, 1H,CH uracil), 7.31-7.65 (m, 3H,Ar-H), 8.45 (br s,1H,NH $\left.{ }^{*}\right) .{ }^{13} \mathrm{C}-\mathrm{NMR}\left(\mathrm{DMSO}_{6}, 100 \mathrm{MHz}\right)$ : $\delta 61.0,61.4,70.2,71.6,80.5,100.1,115.4,116.4,122.8,125.9,129.6,129.8,152.1,152.2,163.2$. MS (EI) $m / z: 480.10$. Anal. Calcd for $\mathrm{C}_{15} \mathrm{H}_{16} \mathrm{Br}_{2} \mathrm{~N}_{2} \mathrm{O}_{6}: \mathrm{C}, 37.53 ; \mathrm{H}, 3.36 ; \mathrm{N}, 5.83$. Found $\mathrm{C}$, $37.48 ; \mathrm{H}, 3.39 ; \mathrm{N}, 5.89$.

1-(B-D-Ribofuranosyl)-6-(2,4-dibromophenoxy methyl) uracil (12)

Yield: $2.8 \mathrm{~g}$ (67\%), m.p. 133-135 ${ }^{\circ} \mathrm{C} .{ }^{1} \mathrm{H}-\mathrm{NMR}$ (DMSO-d $\left.{ }_{6}, 400 \mathrm{MHz}\right): \delta 3.41-3.45$ (m, 2H, H-5',5') , 3.57-3.61(m, 1H,H-4'), 3.71-3.86 (m, 1H,H-3'), 4.10-4.23 (M,1H,H-2'), 4.15 $\left(\mathrm{d}, 1 \mathrm{H}, \mathrm{OH}^{*}\right), 4.54\left(\mathrm{~d}, 1 \mathrm{H}, \mathrm{OH}^{*}\right), 4.60(\mathrm{~d}, 1 \mathrm{H}, \mathrm{OH}), 4.9\left(\mathrm{~s}, 2 \mathrm{H}, \mathrm{CH}_{2}\right.$ phenoxy), $5.13(\mathrm{~m}, 1 \mathrm{H}, \mathrm{OH})$, 5.72 (s,1H,CH uracil), 6.08 (d,1H,7.75 Hz,H-1'),7.20-7.72 (m, 3H,Ar-H), 11.92 (br s, 1H,NH). ${ }^{13}$ C-NMR (DMSO-d $\left.{ }_{6}, 100 \mathrm{MHz}\right): \delta 62.6,65.7,70.5,71.2,84.6,87.7,98.1,115.6,122.8,125.8$, 128.6, 129.9, 150.4, 152.2, 163.0. MS (EI) m/z: $508.11\left(\mathrm{M}^{+}, 15.4 \%\right), 510.12(\mathrm{M}+2,14.46 \%)$. Anal. Calcd for $\mathrm{C}_{16} \mathrm{H}_{16} \mathrm{Br}_{2} \mathrm{~N}_{2} \mathrm{O}_{7}$ : C, 37.82; H, 3.17; N, 5.51. Found C, 37.78; H, 3.29; N, 5.60.

6-(2,4-Dibromophenoxy)methyl)-1-((2R,4S,5R)-4-hydroxy-5-(hydroxylmethyl)tetrahydrofuran-2-yl)pyrimidine-2,4-(1H,3H)-dione (13)

Yield: $2.6 \mathrm{~g}$ (70\%), m.p. 186-188 ${ }^{\circ} \mathrm{C} .{ }^{1} \mathrm{H}-\mathrm{NMR}$ (DMSO-d $\left.{ }_{6}, 400 \mathrm{MHz}\right): \delta 2.24-2.26$ (m, 2H, H-2' , 2"),3.14-3.36 (m, 2H, H-5',5"'), 3.75 (br s, 2H, 2* OH), 4.53 (m, 1H,H-3'), 4.74 (s, $2 \mathrm{H}, \mathrm{CH}_{2}$ phenoxy), $5.11\left(\mathrm{~m}, 1 \mathrm{H}, 4-\mathrm{H}^{\prime}\right), 5,34$ (s, $1 \mathrm{H}, \mathrm{CH}$ uracil), $5.57\left(\mathrm{~m}, 1 \mathrm{H}, \mathrm{H}-1^{\prime}\right), 7.08-7.71$ (m, 3H, Ar-H), 10.92 (br s, 1H, NH). ${ }^{13}$ C-NMR (DMSO-d 6,100 MHz): $\delta 61.7,62.6,65.7,70.9$, $71.5,81.4,86.0,87.7,98.1,115.6,122.9,125.8,128.6,129.9,150.7,151.1,152.2,163.2$. MS (EI) m/z: $492.11\left(\mathrm{M}^{+}, 12.8 \%\right), 494.11(\mathrm{M}+2,11.7 \%)$. Anal. Calcd for $\mathrm{C}_{16} \mathrm{H}_{16} \mathrm{Br}_{2} \mathrm{~N}_{2} \mathrm{O}_{6}$ : C, 39.05; $\mathrm{H}$, 3.28; N, 5.69. Found C, 39.08; H, 3.27; N, 5.63. 
1-(ß-D-Glucopyranosyl)-6-(2,4-dibromophenoxy methyl) uracil (14)

Yield: $2.8 \mathrm{~g}(60.5 \%)$, m.p. $205-207^{\circ} \mathrm{C} .{ }^{1} \mathrm{H}-\mathrm{NMR}$ (DMSO-d $\left.{ }_{6}, 400 \mathrm{MHz}\right): \delta 2.82-2.94(\mathrm{~m}$, $\left.1 \mathrm{H}, 3 \mathrm{H}-3^{\prime}\right), 3.18-3.48$ (m, 4H, H-4', H-5', H-6', 6"), 4.12 (dd, 1H, J1,2 $=9.96, \mathrm{~J}_{2,3}=9.16 \mathrm{~Hz}$, $\left.\mathrm{H}-2^{\prime}\right), 4.14(\mathrm{~m}, 4 \mathrm{H}, 4 \mathrm{OHs}), 4.72\left(\mathrm{~s}, 2 \mathrm{H}, \mathrm{CH}_{2}\right.$ phenoxy), $5.33\left(\mathrm{~d}, 1 \mathrm{H}, \mathrm{J}=9.96 \mathrm{~Hz}, \mathrm{H}-\mathrm{1}^{\prime}\right), 5.55$ (s, $1 \mathrm{H}, \mathrm{CH}$ uracil), 7.04-7.68 (m, 3H, Ar-H), 8.12(br s, $1 \mathrm{H}, \mathrm{NH}^{*}$ ). ${ }^{13} \mathrm{C}-\mathrm{NMR}$ (DMSO-d $\mathrm{d}_{6}$, $100 \mathrm{MHz}): \delta 61.1,65.2,68.4,70.9,78.7,81.6,83.4,96.9,99.2,115.8,122.7,125.7,128.6,129.6$, 152.3, 163.8, 166.6. MS (EI) $\mathrm{m} / \mathrm{z}: 538.14\left(\mathrm{M}^{+}, 9.8 \%\right), 540.14(\mathrm{M}+2,8.7 \%)$. Anal. Calcd for $\mathrm{C}_{17} \mathrm{H}_{18} \mathrm{Br}_{2} \mathrm{~N}_{2} \mathrm{O}_{8}: \mathrm{C}, 37.94 ; \mathrm{H}, 3.37 ; \mathrm{N}, 5.21$. Found $\mathrm{C}, 37.88 ; \mathrm{H}, 3.39 ; \mathrm{N}, 5.35$.

\subsection{Biology}

\subsubsection{Cell and Virus}

HSV-1 propagation was carried out using the African green monkey kidney cell line (Vero). To culture the cells Dulbeco minimum (Gibco, Paisley, UK) with 10\% fetal bovine serum (Gibco) was used. An HSV-1 KOS strain was used examine antiviral activity. Vero cells were used to propagate the virus and the propagated viral stock titer stock was then fixed as TCID $50 \mathrm{~mL}^{-1}$ by using Karber's method. Finally, after the titration, the viral stock was dispensed in sterile tubes, which were then stored at $-70^{\circ} \mathrm{C}$ for later use [66].

\subsubsection{Preparation of Tested Compounds and the Standard}

ACV was purchased from Sigma (St. Louis, MO, USA), and the tested compounds were prepared as previously described. Dimethyl sulfoxide (DMSO) was used as a solvent for the tested compounds and ACV.

\subsubsection{Antiherpetic Activity Assay}

A CPE inhibition assay was used to determine the semi-quantitative antiviral activity of the 12 tested compounds according to [66]. In most studies, DMSO showed an antiviral effect in vitro on different cell types [67]; thus, the concentration of DMSO should be less than 25, which is the lowest allowed concentration for an antiviral effect. Therefore, we ignored its effect in our study when it was used as a solvent for the targeted compounds. The degree of inhibition was expressed as a throughput percentage of virus control (\% virus control $=\mathrm{CPE}$ experimental group $/ \mathrm{CPE}$ virus control $\times 100$ ) [66]. The antiviral activity was also expressed as the EC50, which is the concentration required to reduce a virus-induced $\mathrm{CPE}$ or viral plaque formation by $50 \%$ compared to the untreated control [2].

\section{Conclusions}

In this research, we presented some new synthetic nucleoside analogues having good activity against HSV-1 equal to or higher than the standard drug, ACV. The acyclic nucleosides predominated over the cyclic forms, with acyclic compounds 6 and 8 giving the highest activities). They induced total prevention of viral CPE presentation at a concentration of $36 \mu \mathrm{g} / \mathrm{mL}$, which was less than that needed by ACV $(42 \mu \mathrm{g} / \mathrm{mL})$. The $\mathrm{EC}_{50}$ values of the compounds were (15.76 and 15.19, respectively, which was close to that of ACV (13.96). Such compounds could be used as alternatives to the currently used antiherpetic drugs, which have major disadvantages such as acquired viral resistance that has become life threatening, especially for immunocompromised patients. With the fact that some antiviral nucleoside analogues are actually being used in some clinical trials to treat SARS-CoV-2, our nucleoside analogues could also serve as promising anti-COVID agents, but of course that needs further study.

Supplementary Materials: The following are available online at. ${ }^{1} \mathrm{HNMR}$ and ${ }^{13} \mathrm{C}$ NMRspectra copies.

Author Contributions: Conceptualization, S.S.F., and S.M.A. (Samir Mohamed Awad); methodology, S.S.F., S.M.A. (Shima Mahmoud Ali) and S.M.A. (Samir Mohamed Awad); validation, S.S.F., S.M.A. (Shima Mahmoud Ali), Y.E.M. and S.M.A. (Samir Mohamed Awad); writing—original draft preparation, S.S.F., S.M.A. (Shima Mahmoud Ali); writing—review and editing, S.S.F., S.M.A. (Shima 
Mahmoud Ali), Y.E.M. and S.M.A. (Samir Mohamed Awad); visualization, S.S.F., Y.E.M. All authors have read and agreed to the published version of the manuscript.

Funding: This research received no external funding.

Institutional Review Board Statement: Not applicable.

Informed Consent Statement: Not applicable.

Data Availability Statement: The data presented in this study are available on request from the corresponding author.

Conflicts of Interest: We are self-funded researchers, and we have confirmed this; this research did not obtain any specific grant from any commercial or non-profit public funding agency. No potential conflict of interest has been reported by the authors. Neither humans nor animals were used for the basic studies of this research.

\section{References}

1. Jiang, Y.C.; Feng, H.; Lin, Y.C.; Guo, X.R. New strategies against drug resistance to herpes simplex virus. Int. J. Oral Sci. 2016, 8, 1-6. [CrossRef]

2. Coen, N.; Singh, U.; Vuyyuru, V.; Van den Oord, J.J.; Balzarini, J.; Duraffour, S.; Snoeck, R.; Cheng, Y.C.; Chu, C.K.; Andrei, G. Activity and Mechanism of Action of HDVD, a Novel Pyrimidine Nucleoside Derivative with High Levels of Selectivity and Potency against Gammaherpesviruses. J. Virol. 2013, 87, 3839-3851. [CrossRef]

3. Wilson, S.S.; Fakioglu, E.; Herold, B.C. Novel approaches in fighting herpes simplex virus infections. Expert Rev. Anti Infect. Ther. 2009, 7, 559-568. [CrossRef] [PubMed]

4. Aichelburg, M.C.; Weseslindtner, L.; Mandorfer, M.; Strassl, R.; Rieger, A.; Reiberger, T.; Puchhammer-Stöckl, E.; GrabmeierPfistershammer, K. Association of CMV-specific T cell-mediated immunity with CMV DNAemia and development of CMV disease in HIV-1-infected individuals. PLoS ONE 2015, 10, e0137096. [CrossRef]

5. Hill, J.A.; Boeckh, M.J.; Sedlak, R.H.; Jerome, K.R.; Zerr, D.M. Human herpesvirus 6 can be detected in cerebrospinal fluid without associated symptoms after allogeneic hematopoietic cell transplantation. J. Clin. Virol. 2014, 61, 289-292. [CrossRef]

6. Lei, X.; Bai, Z.; Ye, F.; Huang, Y.; Gao, S.J. Regulation of herpesvirus lifecycle by viral microRNAs. Virulence 2010, 1, $433-435$. [CrossRef]

7. Gilbert, C.; Bestman-Smith, J.; Boivin, G. Resistance of herpesviruses to antiviral drugs: Clinical impacts and molecular mechanisms. Drug Resist. Updates 2002, 5, 88-114. [CrossRef]

8. De Clercq, E. Selective anti-herpesvirus agents. Antivir. Chem. Chemother. 2013, 23, 93-101. [CrossRef]

9. De Clercq, E. Nucleoside Analogues Exerting Antiviral Activity through a Non-nucleoside Mechanism. Nucleosides Nucleotides Nucleic Acids 2004, 23, 457-470. [CrossRef]

10. El-Din Abuo-Rahma, G.A.; Mohamed, M.F.A.; Ibrahim, T.S.; Shoman, M.E.; Samir, E.; Abd El-Baky, R.M. Potential repurposed SARS-CoV-2 (COVID-19) infection drugs. RSC Adv. 2020, 10, 26895-26916. [CrossRef]

11. Andrei, G.; Snoeck, R. Emerging drugs for varicella-zoster virus infections. Expert Opin. Emerg. Drugs 2011, 16, 507-535. [CrossRef]

12. Ramesh, D.; Vijayakumar, B.G.; Kannan, T. Therapeutic potential of uracil and its derivatives in countering pathogenic and physiological disorders. Eur. J. Med. Chem. 2020, 207, 112801. [CrossRef] [PubMed]

13. De Clercq, E.; Holý, A. Case history: Acyclic nucleoside phosphonates: A key class of antiviral drugs. Nat. Rev. Drug Discov. 2005, 4, 928-940. [CrossRef] [PubMed]

14. Onishi, T.; Mukai, C.; Nakagawa, R.; Sekiyama, T.; Aoki, M.; Suzuki, K.; Nakazawa, H.; Ono, N.; Ohmura, Y.; Iwayama, S.; et al. Synthesis and antiviral activity of novel anti-VZV 5-substituted uracil nucleosides with a cyclopropane sugar moiety. J. Med. Chem. 2000, 43, 278-282. [CrossRef] [PubMed]

15. Shigeta, S.; Mori, S.; Kira, T.; Takahashi, K.; Kodama, E.; Konno, K.; Nagata, T.; Kato, H.; Wakayama, T.; Koike, N.; et al. Anti-herpesvirus activities and cytotoxicities of 2-thiopyrimidine nucleoside analogues in vitro. Antivir. Chem. Chemother. 1999, 10, 195-209. [CrossRef] [PubMed]

16. Choi, Y.; Li, L.; Grill, S.; Gullen, E.; Lee, C.S.; Gumina, G.; Tsujii, E.; Cheng, Y.C.; Chu, C.K. Structure-activity relationships of (E)-5(2-bromovinyl)uracil and related pyrimidine nucleosides as antiviral agents for herpes viruses. J. Med. Chem. 2000, 43, $2538-2546$. [CrossRef] [PubMed]

17. De Clercq, E. Guanosine analogues as anti-herpesvirus agents. Nucleosides Nucleotides Nucleic Acids 2000, 19, 1531-1541. [CrossRef]

18. Machida, H.; Sakata, S.; Ashida, N.; Takenuki, K.; Matsuda, A. In vitro anti-herpesvirus activities of 5-substituted 2'-deoxy-2' methylidene pyrimidine nucleosides. Antivir. Chem. Chemother. 1993, 4, 11-17. [CrossRef]

19. Pałasz, A.; Ciez, D. In search of uracil derivatives as bioactive agents. Uracils and fused uracils: Synthesis, biological activity and applications. Eur. J. Med. Chem. 2015, 97, 582-611. [CrossRef]

20. Katsuyama, A.; Ichikawa, S. Medicinal and Bioorganic Chemistry of Nucleosides and Nucleotides Synthesis and Medicinal Chemistry of Muraymycins, Nucleoside Antibiotics. Chem. Pharm. Bull. 2018, 66, 139-146. [CrossRef] [PubMed] 
21. De Clercq, E. Antivirals and antiviral strategies. Nat. Rev. Microbiol. 2004, 2, 704-720. [CrossRef] [PubMed]

22. Mahmoud, S.; Hasabelnaby, S.; Hammad, S.; Sakr, T. Antiviral Nucleoside and Nucleotide Analogs: A Review. J. Adv. Pharm. Res. 2018, 2, 73-88. [CrossRef]

23. Azzam, R.A.; Osman, R.R.; Elgemeie, G.H. Efficient Synthesis and Docking Studies of Novel Benzothiazole-Based Pyrimidinesulfonamide Scaffolds as New Antiviral Agents and Hsp90 $\alpha$ Inhibitors. ACS Omega 2020, 5, 1640-1655. [CrossRef]

24. Pona, A.; Jiwani, R.A.; Afriyie, F.; Labbe, J.; Cook, P.P.; Mao, Y. Herpes zoster as a potential complication of coronavirus disease 2019. Dermatol. Ther. 2020, 18-19. [CrossRef] [PubMed]

25. Altayeb, H.; Bouslama, L.; Abdulhakimc, J.A.; Chaieb, K.; Baothman, O.; Zamzami, M. Potential activity of a selected natural compounds on SARS-CoV-2 RNA-dependent-RNA polymerase, and binding affinity of the receptor-binding domain (RBD). Res. Sq. 2020, 1-39. [CrossRef]

26. Wang, Y.; Anirudhan, V.; Du, R.; Cui, Q.; Rong, L. RNA-dependent RNA polymerase of SARS-CoV-2 as a therapeutic target. J. Med. Virol. 2020. [CrossRef] [PubMed]

27. Machitani, M.; Yasukawa, M.; Nakashima, J.; Furuichi, Y.; Masutomi, K. RNA-dependent RNA polymerase, RdRP, a promising therapeutic target for cancer and potentially COVID-19. Cancer Sci. 2020, 111, 3976-3984. [CrossRef]

28. Mancilla-Galindo, J.; Óscar García-Méndez, J.; Márquez-Sánchez, J.; Reyes-Casarrubias, R.E.; Aguirre-Aguilar, E.; Rocha-González, H.I.; Kammar-García, A. Use of antivirals and antibiotics for COVID-19 in Mexico City: A Real-World Multicenter Cohort Study. MedRxiv 2020. [CrossRef]

29. Gao, Y.; Yan, L.; Huang, Y.; Liu, F.; Zhao, Y.; Cao, L.; Wang, T.; Sun, Q.; Ming, Z.; Zhang, L.; et al. Structure of the RNA-dependent RNA polymerase from COVID-19 virus. Science 2020, 368, 779-782. [CrossRef]

30. Bocci, G.; Bradfute, S.B.; Ye, C.; Garcia, M.J.; Parvathareddy, J.; Reichard, W.; Surendranathan, S.; Bansal, S.; Bologa, C.G.; Perkins, D.J.; et al. Virtual and in Vitro Antiviral Screening Revive Therapeutic Drugs for COVID-19. ACS Pharmacol. Transl. Sci. 2020, 3, 1278-1292. [CrossRef]

31. Yin, W.; Mao, C.; Luan, X.; Shen, D.D.; Shen, Q.; Su, H.; Wang, X.; Zhou, F.; Zhao, W.; Gao, M.; et al. Structural basis for inhibition of the RNA-dependent RNA polymerase from SARS-CoV-2 by remdesivir. Science 2020, 368, 1499-1504. [CrossRef] [PubMed]

32. Jockusch, S.; Tao, C.; Li, X.; Anderson, T.K.; Chien, M.; Kumar, S.; Russo, J.J.; Kirchdoerfer, R.N.; Ju, J. A library of nucleotide analogues terminate RNA synthesis catalyzed by polymerases of coronaviruses that cause SARS and COVID-19. Antivir. Res. 2020, 180, 104857. [CrossRef] [PubMed]

33. Mocarski, E.S., Jr. Comparative analysis of herpesvirus-common proteins. In Human Herpesviruses: Biology, Therapy, and Immunoprophylaxis; Cambridge University Press: Cambridge, UK, 2007; Chapter 4; pp. 1-17.

34. Zhao, J.; Qin, C.; Liu, Y.; Rao, Y.; Feng, P. Herpes Simplex Virus and Pattern Recognition Receptors: An Arms Race. Front. Immunol. 2021, 11, 1-10. [CrossRef] [PubMed]

35. De Clercq, E.; Li, G. Approved antiviral drugs over the past 50 years. Clin. Microbiol. Rev. 2016, 29, 695-747. [CrossRef] [PubMed]

36. Coen, N.; Duraffour, S.; Snoeck, R.; Andrei, G. KSHV targeted therapy: An update on inhibitors of viral lytic replication. Viruses 2014, 6, 4731-4759. [CrossRef]

37. Madavaraju, K.; Koganti, R.; Volety, I.; Yadavalli, T.; Shukla, D. Herpes Simplex Virus Cell Entry Mechanisms: An Update. Front. Cell. Infect. Microbiol. 2021, 10, 1-18. [CrossRef] [PubMed]

38. Stebbing, J.; Phelan, A.; Griffin, I.; Tucker, C.; Oechsle, O.; Smith, D.; Richardson, P. COVID-19: Combining antiviral and anti-inflammatory treatments. Lancet Infect. Dis. 2020, 20, 400-402. [CrossRef]

39. Heidary, F.; Gharebaghi, R. Ivermectin: A systematic review from antiviral effects to COVID-19 complementary regimen. J. Antibiot. 2020, 73, 593-602. [CrossRef]

40. Niedballa, U.; Vorbrüggen, H. A General Synthesis of N-Glycosides. I. Synthesis of Pyrimidine Nucleosides. J. Org. Chem. 1974, 39, 3654-3660. [CrossRef]

41. Vorbrüggen, H.; Krolikiewicz, K.; Bennua, B. Nucleoside syntheses, XXII1) Nucleoside synthesis with trimethylsilyl triflate and perchlorate as catalysts. Chem. Ber. 1981, 114, 1234-1255. [CrossRef]

42. Niedballa, U.; Vorbrüggen, H. A General Synthesis of N-Glycosides. 6. On the Mechanism of the Stannic Chloride Catalyzed Silyl Hilbert-Johnson Reaction. J. Org. Chem. 1976, 41, 2084-2086. [CrossRef]

43. Andersen, G.W.; Halverstadt, I.F.; Miller, W.H.; Roblin, R.O. Studies in Chemotherapy. X. Antithyroid Compounds. Synthesis of 5- and 6- Substituted 2-Thiouracils from $\beta$-Oxoesters and Thiourea. J. Am. Chem. Soc. 1945, 67, 2197-2200. [CrossRef]

44. El-Telbani, E.M.; El Shehry, M.F.; Nawwar, G.A.M. Meldrum's acid in heterocyclic synthesis: Azoles incorporating a 2,4dichlorophenoxy moiety with anticipated molluscicidal activity. Monatshefte fur Chemie 2008, 139, 685-689. [CrossRef]

45. Elshehry, M.F.; Balzarini, J.; Meier, C. Synthesis of new cyclic and acyclic 5-halouridine derivatives as potential antiviral agents. Synthesis 2009, 841-847. [CrossRef]

46. Meier, L.; Monteiro, G.C.; Baldissera, R.A.M.; Sá, M.M. Simple method for fast deprotection of nucleosides by triethylaminecatalyzed methanolysis of acetates in aqueous medium. J. Braz. Chem. Soc. 2010, 21, 859-866. [CrossRef]

47. McCabe Dunn, J.M.; Reibarkh, M.; Sherer, E.C.; Orr, R.K.; Ruck, R.T.; Simmons, B.; Bellomo, A. The protecting-group free selective 3'-functionalization of nucleosides. Chem. Sci. 2017, 8, 2804-2810. [CrossRef] [PubMed]

48. Sauer, R.; El-Tayeb, A.; Kaulich, M.; Müller, C.E. Synthesis of uracil nucleotide analogs with a modified, acyclic ribose moiety as P2Y2 receptor antagonists. Bioorg. Med. Chem. 2009, 17, 5071-5079. [CrossRef] [PubMed] 
49. Boháčová, S.; Ludvíková, L.; Poštová Slavětínská, L.; Vaníková, Z.; Klán, P.; Hocek, M. Protected 5-(hydroxymethyl)uracil nucleotides bearing visible-light photocleavable groups as building blocks for polymerase synthesis of photocaged DNA. Org. Biomol. Chem. 2018, 16, 1527-1535. [CrossRef] [PubMed]

50. Vorbrüggen, H.; Bennua, B. Nucleoside syntheses, XXV1) A new simplified nucleoside synthesis. Chem. Ber. 1981, 114, 1279-1286. [CrossRef]

51. Reefschläger, J.; Herrmann, G.; Bärwolff, D.; Schwarz, B.; Cech, D.; Langen, P. Antiherpes activity of (E)-5-(2-bromovinyl)and 5-vinyl-1- $\beta$-D-arabinofuranosyluracil and some other 5-substituted uracil arabinosyl nucleosides in two different cell lines. Antivir. Res. 1983, 3, 175-187. [CrossRef]

52. Mattelaer, H.P.; Van Hool, A.S.; de Jong, F.; Van der Auweraer, M.; Van Meervelt, L.; Dehaen, W.; Herdewijn, P. New Metal-Free Route towards Imidazole-Substituted Uridine. Eur. J. Org. Chem. 2020, 2020, 4022-4025. [CrossRef] [PubMed]

53. Crute, J.J.; Lehman, I.R. Herpes simplex-1 DNA polymerase. Identification of an intrinsic $5^{\prime} \rightarrow 3^{\prime}$ exonuclease with ribonuclease $\mathrm{H}$ activity. J. Biol. Chem. 1989, 264, 19266-19270. [CrossRef]

54. Weller, S.K.; Coen, D.M. Herpes simplex viruses: Mechanisms of DNA replication. Cold Spring Harb. Perspect. Biol. 2012, 4, 1-14. [CrossRef] [PubMed]

55. Bednarski, K.; Dixit, D.M.; Wang, W.; Evans, C.A.; Jin, H.; Yuen, L.; Mansour, T.S. Inhibitory activities of herpes simplex viruses type 1 and 2 and human cytomegalovirus by stereoisomers of $2^{\prime}$-deoxy-3'-oxa-5(E)-(2-bromovinyl)uridines and their $4^{\prime}$-thio analogues. Bioorg. Med. Chem. Lett. 1994, 4, 2667-2672. [CrossRef]

56. Piret, J.; Boivin, G. Resistance of herpes simplex viruses to nucleoside analogues: Mechanisms, prevalence, and management. Antimicrob. Agents Chemother. 2011, 55, 459-472. [CrossRef] [PubMed]

57. Schnitzler, P.; Koch, C.; Reichling, J. Susceptibility of drug-resistant clinical herpes simplex virus type 1 strains to essential oils of ginger, thyme, hyssop, and sandalwood. Antimicrob. Agents Chemother. 2007, 51, 1859-1862. [CrossRef]

58. Czartoski, T.; Liu, C.; Koelle, D.M.; Schmechel, S.; Kalus, A.; Wald, A. Fulminant, acyclovir-resistant, herpes simplex virus type 2 hepatitis in an immunocompetent woman. J. Clin. Microbiol. 2006, 44, 1584-1586. [CrossRef]

59. Razonable, R.R. Antiviral drugs for viruses other than human immunodeficiency virus. Mayo Clin. Proc. 2011, 86, 1009-1026. [CrossRef]

60. Chrisp, P.; Clissold, S.P. Foscarnet: A Review of its Antiviral Activity, Pharmacokinetic Properties and Therapeutic Use in Immunocompromised Patients with Cytomegalovirus Retinitis. Drugs 1991, 41, 104-129. [CrossRef]

61. Kotton, C.N.; Kumar, D.; Caliendo, A.M.; Åsberg, A.; Chou, S.; Snydman, D.R.; Allen, U.; Humar, A.; Emery, V.; Lautenschlager, I.; et al. International consensus guidelines on the management of cytomegalovirus in solid organ transplantation. Transplantation 2010, 89, 779-795. [CrossRef]

62. Humar, A.; Snydman, D. Cytomegalovirus in solid organ transplant recipients. Am. J. Transplant. 2009, 9, 78-86. [CrossRef] [PubMed]

63. Garvey, L.; Thomson, E.C.; Taylor, G.P. Progressive multifocal leukoencephalopathy: Prolonged survival in patients treated with protease inhibitors and cidofovir: A case series. AIDS 2006, 20, 791-793. [CrossRef] [PubMed]

64. LoPresti, A.E.; Levine, J.F.; Munk, G.B.; Tai, C.Y.; Mendel, D.B. Successful treatment of an acyclovir- and foscarnet- resistant herpes virus simplex virus type 1 lesion with intravenous cidofovir. Clin. Infect. Dis. 1998, 26, 512-513. [CrossRef]

65. Bestman-Smith, J.; Boivin, G. Drug Resistance Patterns of Recombinant Herpes Simplex Virus DNA Polymerase Mutants Generated with a Set of Overlapping Cosmids and Plasmids. J. Virol. 2003, 77, 7820-7829. [CrossRef] [PubMed]

66. Zandi, K.; Ramedani, E.; Khosro, M.; Tajbakhsh, S.; Dailami, I.; Rastian, Z.; Fouladvand, M.; Yousefi, F.; Farshadpour, F. Natural Product Communications Evaluation of Antiviral Activities of Curcumin Derivatives. Nat. Prod. Commun. 2010, 5, 8-11.

67. Aguilar, J.S.; Roy, D.; Ghazal, P.; Wagner, E.K. Dimethyl sulfoxide blocks herpes simplex virus-I productive infection in vitro acting at different stages with positive cooperativity. Application of micro-array analysis. BMC Infect. Dis. 2002, 2, 1-10. [CrossRef] [PubMed] 